\title{
ARTICLE
}

Received 2 Jun 2015 | Accepted 30 Mar 2016 | Published 4 May 2016

DOI: $10.1038 /$ ncomms11470

OPEN

\section{Seawater usable for production and consumption of hydrogen peroxide as a solar fuel}

Kentaro Mase ${ }^{1}$, Masaki Yoneda ${ }^{1}$, Yusuke Yamada ${ }^{2} \&$ Shunichi Fukuzumi 1,3,4

Hydrogen peroxide $\left(\mathrm{H}_{2} \mathrm{O}_{2}\right)$ in water has been proposed as a promising solar fuel instead of gaseous hydrogen because of advantages on easy storage and high energy density, being used as a fuel of a one-compartment $\mathrm{H}_{2} \mathrm{O}_{2}$ fuel cell for producing electricity on demand with emitting only dioxygen $\left(\mathrm{O}_{2}\right)$ and water. It is highly desired to utilize the most earth-abundant seawater instead of precious pure water for the practical use of $\mathrm{H}_{2} \mathrm{O}_{2}$ as a solar fuel. Here we have achieved efficient photocatalytic production of $\mathrm{H}_{2} \mathrm{O}_{2}$ from the most earth-abundant seawater instead of precious pure water and $\mathrm{O}_{2}$ in a two-compartment photoelectrochemical cell using $\mathrm{WO}_{3}$ as a photocatalyst for water oxidation and a cobalt complex supported on a glassy-carbon substrate for the selective two-electron reduction of $\mathrm{O}_{2}$. The concentration of $\mathrm{H}_{2} \mathrm{O}_{2}$ produced in seawater reached $48 \mathrm{mM}$, which was high enough to operate an $\mathrm{H}_{2} \mathrm{O}_{2}$ fuel cell.

\footnotetext{
${ }^{1}$ Department of Material and Life Science, Graduate School of Engineering, Osaka University, ALCA and SENTAN, Japan Science and Technology Agency (JST), Suita, Osaka 565-0871, Japan. ${ }^{2}$ Department of Applied Chemistry and Bioengineering, Graduate School of Engineering, Osaka City University, Osaka 558-8585, Japan. ${ }^{3}$ Faculty of Science and Technology, Meijo University, ALCA and SENTAN, Japan Science and Technology Agency, JST, Shiogamaguchi, Tenpaku, Nagoya, Aichi 468-8502, Japan. ${ }^{4}$ Department of Chemistry and Nano Science, Ewha Womans University, Seoul 120-750, Korea. Correspondence and requests for materials should be addressed to S.F. (email: fukuzumi@chem.eng.osaka-u.ac.jp).
} 
U tilization of solar energy as a primary energy source has been strongly demanded to reduce emissions of harmful and/or greenhouse gases produced by burning fossil fuels. However, large fluctuation of solar energy depending on the length of the daytime is a serious problem ${ }^{1,2}$. To utilize solar energy in the night time, solar energy should be stored in the form of chemical energy and used as a fuel to produce electricity. In this context, $\mathrm{H}_{2}$ has been regarded as the most promising candidate, because $\mathrm{H}_{2}$ can be produced by photocatalytic water splitting and used as a fuel of $\mathrm{H}_{2}$ fuel cells to generate electricity with a high efficiency without emission of harmful chemicals. However, the low solar energy conversion efficiency of $\mathrm{H}_{2}$ production and the storage problem of gaseous $\mathrm{H}_{2}$ have precluded the practical use of $\mathrm{H}_{2}$ as a solar fuel ${ }^{3}$. In contrast to gaseous $\mathrm{H}_{2}, \mathrm{H}_{2} \mathrm{O}_{2}$ can be produced as an aqueous solution from water and $\mathrm{O}_{2}$ in the air by the combination of the photocatalytic two-electron reduction of $\mathrm{O}_{2}$ and the catalytic four-electron oxidation of water ${ }^{4,5} \cdot \mathrm{H}_{2} \mathrm{O}_{2}$ can be used as a fuel of an $\mathrm{H}_{2} \mathrm{O}_{2}$ fuel cell to generate electricity with emission of water and oxygen ${ }^{5-10}$. The energy density of aqueous $\mathrm{H}_{2} \mathrm{O}_{2}(60 \%)$ is $3.0 \mathrm{MJl}^{-1}$ $\left(2.1 \mathrm{MJ} \mathrm{kg}^{-1}\right)$, which is comparable to the value $\left(2.8 \mathrm{MJl}^{-1}\right.$, $3.5 \mathrm{MJ} \mathrm{kg}^{-1}$ ) of compressed hydrogen $(35 \mathrm{MPa})$. However, the photocatalytic production of $\mathrm{H}_{2} \mathrm{O}_{2}$ from water and $\mathrm{O}_{2}$ has yet to be combined with the consumption of the produced $\mathrm{H}_{2} \mathrm{O}_{2}$ in an $\mathrm{H}_{2} \mathrm{O}_{2}$ fuel cell because of the insufficient photocatalytic activity ${ }^{4,5}$. In order to realize the production of $\mathrm{H}_{2} \mathrm{O}_{2}$ and its use in an $\mathrm{H}_{2} \mathrm{O}_{2}$ fuel cell, a breakthrough is definitely required to improve the photocatalytic efficiency for $\mathrm{H}_{2} \mathrm{O}_{2}$ production.

We report herein efficient photocatalytic production of $\mathrm{H}_{2} \mathrm{O}_{2}$, which has been made possible by using the most earth-abundant resource, that is, seawater instead of pure water for the photocatalytic oxidation with a semiconductor and the catalytic two-electron reduction of $\mathrm{O}_{2}$ with a cobalt chlorin complex supported on a glassy carbon substrate in a two-compartment photoelectrochemical cell under simulated solar illumination without an external bias potential. The $\mathrm{H}_{2} \mathrm{O}_{2}$ produced in seawater was used directly to generate electricity with the open-circuit voltage of $0.78 \mathrm{~V}$ and the maximum power density of $1.6 \mathrm{~mW} \mathrm{~cm}^{-2}$ using an $\mathrm{H}_{2} \mathrm{O}_{2}$ fuel cell, and the solar-to-electricity conversion efficiency of the total system is estimated to be ca $0.28 \%$.

\section{Results}

Performance of photoanode and cathode. As a semiconductor photocatalyst for the water oxidation, tungsten oxide $\left(\mathrm{WO}_{3}\right)$, which has a narrow band gap suitable for visible light $(<460 \mathrm{~nm})$ absorption, was employed ${ }^{11-14}$. In $\mathrm{WO}_{3}$, hole $\left(\mathrm{h}^{+}\right)$generated in the valence band (VB) is positive enough to oxidize water with the long lifetime (equation $(1))^{15}$. The use of seawater instead of pure water has also enabled us to combine the photocatalytic production of $\mathrm{H}_{2} \mathrm{O}_{2}$ from seawater and $\mathrm{O}_{2}$ and its use in an $\mathrm{H}_{2} \mathrm{O}_{2}$ fuel cell. To perform selective reduction of $\mathrm{O}_{2}$, a cobalt chlorin

$$
2 \mathrm{H}_{2} \mathrm{O}+4 \mathrm{~h}^{+} \stackrel{h v}{\longrightarrow} \mathrm{O}_{2}+4 \mathrm{H}^{+}
$$

complex $\left(\mathrm{Co}^{\mathrm{II}}(\mathrm{Ch})\right)$, which has been proved to function as a catalyst for the efficient and selective two-electron reduction of $\mathrm{O}_{2}$ under homogeneous conditions (equation (2)), has been employed $^{16}$. The overall photocatalytic reaction is given by equation (3), thus, $\mathrm{H}_{2} \mathrm{O}_{2}$ can be produced by the two-electron reduction of $\mathrm{O}_{2}$ by water as an electron donor.

$$
\begin{gathered}
\mathrm{O}_{2}+2 \mathrm{H}^{+}+2 \mathrm{e}^{-} \rightarrow \mathrm{H}_{2} \mathrm{O}_{2} \\
2 \mathrm{H}_{2} \mathrm{O}+\mathrm{O}_{2} \stackrel{h v}{\longrightarrow} 2 \mathrm{H}_{2} \mathrm{O}_{2}
\end{gathered}
$$

Mesoporous $\mathrm{WO}_{3}\left(\mathrm{~m}-\mathrm{WO}_{3}\right)$ prepared by a literature method was deposited on a fluorine-doped tin oxide (FTO) as a photoanode $\left(\mathrm{m}-\mathrm{WO}_{3} / \mathrm{FTO}\right)$ and $\mathrm{Co}^{\mathrm{II}}(\mathrm{Ch})$ was adsorbed on a carbon paper (denoted as $\mathrm{CP}$ ) as a cathode $\left(\mathrm{Co}^{\mathrm{II}}(\mathrm{Ch}) / \mathrm{CP}\right.$; see Supplementary Information for details). Photocatalytic production of $\mathrm{H}_{2} \mathrm{O}_{2}$ was performed by using a two-compartment photoelectrochemical cell with the $\mathrm{m}-\mathrm{WO}_{3} / \mathrm{FTO}$ photoanode and the $\mathrm{Co}^{\mathrm{II}}(\mathrm{Ch}) / \mathrm{CP}$ cathode, which were immersed in Ar-saturated and in $\mathrm{O}_{2}$-saturated aqueous $\mathrm{HClO}_{4}$ solutions $(\mathrm{pH}$ 1.3), respectively. These two electrodes were connected to each other by a conducting wire as an external circuit. The cathode and anode cells were separated by a Nafion membrane to prevent the decomposition of $\mathrm{H}_{2} \mathrm{O}_{2}$ produced in the cathode cell. Overall schematic diagram is shown in Fig. 1.

To evaluate the selectivity to the two-electron reduction of $\mathrm{O}_{2}$ with $\mathrm{Co}^{\mathrm{II}}(\mathrm{Ch}) / \mathrm{CP}$, the number of transferred electrons during the catalytic reaction was estimated by performing the rotating ring disc electrode (RRDE) technique with a glassy carbon disk electrode modified with a $\mathrm{Co}^{\mathrm{II}}(\mathrm{Ch})$ adsorbed on multi-walled carbon nanotubes (MWCNTs; see Supplementary Information for details). From the ratio of the observed disk current and the ring current at various rotating rates, the average number of transferred electrons was determined to be 2.7 (70\% selectivity; Supplementary Fig. 1). $\mathrm{Co}^{\mathrm{II}}(\mathrm{Ch})$ has previously been reported to catalyse the production of $\mathrm{H}_{2} \mathrm{O}_{2}$ with nearly $100 \%$ selectivity in $\mathrm{PhCN}$ under homogeneous conditions ${ }^{16}$. The decrease in the selectivity of two-electron reduction of $\mathrm{O}_{2}$ may be attributed to the partial formation of $\mu-1,2$-peroxo $\mathrm{Co}^{\mathrm{III}}(\mathrm{Ch})$ dimer, which has been reported to act as a reactive intermediate in the four-electron reduction of $\mathrm{O}_{2}$ (ref. 17).

Photocatalytic production of $\mathbf{H}_{2} \mathbf{O}_{2}$. The simulated 1 sun illumination of $\mathrm{m}-\mathrm{WO}_{3} / \mathrm{FTO}$ in the anode cell afforded the efficient photocatalytic production of $\mathrm{H}_{2} \mathrm{O}_{2}$ in the cathode cell in the two-compartment photoelectrochemical configuration without an external bias potential. The time courses of photocatalytic $\mathrm{H}_{2} \mathrm{O}_{2}$ production are shown in Fig. 2. Very little amount of $\mathrm{H}_{2} \mathrm{O}_{2}$ was obtained in the absence of $\mathrm{Co}^{\mathrm{II}}(\mathrm{Ch})$ on $\mathrm{CP}$ electrode, indicating that $\mathrm{Co}^{\mathrm{II}}(\mathrm{Ch})$ adsorbed on $\mathrm{CP}$ efficiently catalyses the two-electron reduction of $\mathrm{O}_{2}$ to produce $\mathrm{H}_{2} \mathrm{O}_{2}$ before the charge recombination of photoexcited electron in conduction band and $\mathrm{h}^{+}$in $\mathrm{VB}$ of $\mathrm{WO}_{3}$. The rate of photocatalytic production of $\mathrm{H}_{2} \mathrm{O}_{2}$ in seawater was markedly enhanced compared with that in pure water. After the illumination for $24 \mathrm{~h}$, the amount of produced $\mathrm{H}_{2} \mathrm{O}_{2}$ in seawater reached ca $48 \mathrm{mM}$, which is much larger than the value $(2 \mathrm{mM})$ using a one-compartment system reported previously ${ }^{4}$. No structural change of $\mathrm{m}-\mathrm{WO}_{3} / \mathrm{FTO}$ electrode after

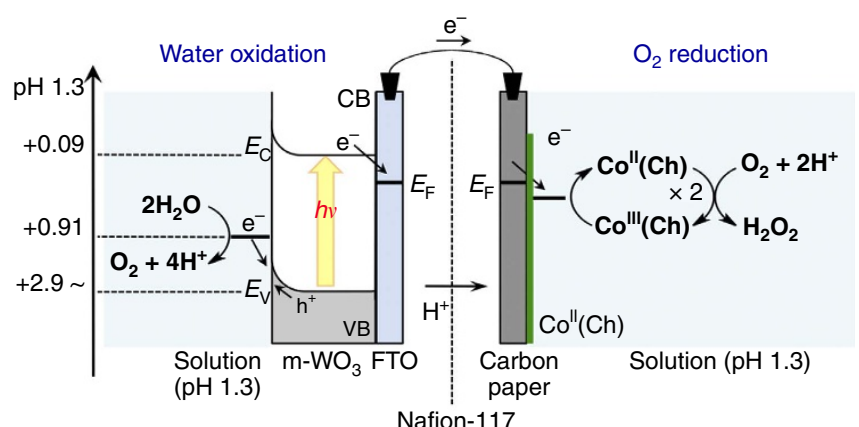

Figure 1 | Overall scheme of photocatalytic production of $\mathrm{H}_{\mathbf{2}} \mathbf{O}_{\mathbf{2}}$.

Photocatalytic production of $\mathrm{H}_{2} \mathrm{O}_{2}$ from water and $\mathrm{O}_{2}$ using $\mathrm{m}-\mathrm{WO}_{3} /$ FTO photoanode and $\mathrm{Co}^{\prime \prime}(\mathrm{Ch}) / \mathrm{CP}$ cathode in water or seawater under simulated 1 sun (AM 1.5G) illumination. 


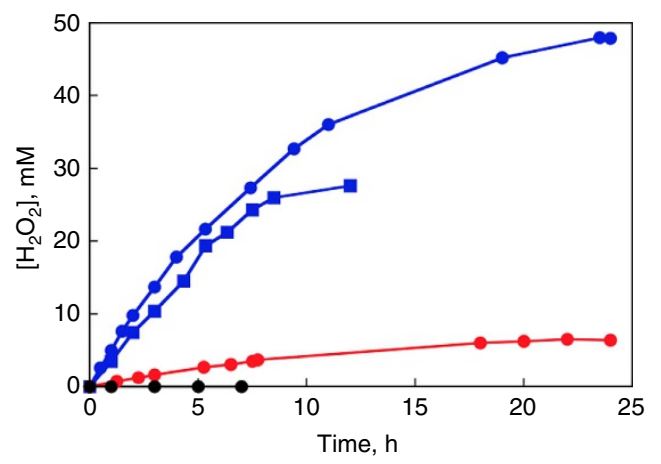

Figure 2 | Photocatalytic production of $\mathrm{H}_{2} \mathrm{O}_{2}$ in the two-compartment photoelectrochemical cell. Time courses of $\mathrm{H}_{2} \mathrm{O}_{2}$ production with $\mathrm{m}-\mathrm{WO}_{3} /$ FTO photoanode and $\mathrm{Co}^{\mathrm{Il}}(\mathrm{Ch}) / \mathrm{CP}$ cathode in $\mathrm{pH} 1.3$ water (red circle), in $\mathrm{pH} 1.3$ seawater (blue circle) and in an $\mathrm{NaCl}$ aqueous solution $(\mathrm{pH} 1.3$; blue square) under simulated 1 sun ( $A M$ 1.5G) illumination. Time course of $\mathrm{H}_{2} \mathrm{O}_{2}$ production in the absence of $\mathrm{Co}^{11}(\mathrm{Ch})$ on carbon paper under simulated 1 sun (AM 1.5G) illumination in $\mathrm{pH} 1.3$ water is shown as black circle.

the photocatalytic reaction was confirmed by the powder X-ray diffraction measurements (Supplementary Fig. 2). The similar enhancement on photocatalytic activity was observed in an $\mathrm{NaCl}$ solution, in which the concentration of $\mathrm{Cl}^{-}$was the same as that of $\mathrm{Cl}^{-}$in seawater. The enhancement effect of $\mathrm{Cl}^{-}$on the photocatalytic activity for water oxidation can be interpreted by the following $\mathrm{Cl}^{-}$-assisted mechanism ${ }^{18-21}$. First, the oxidation of $\mathrm{Cl}^{-}$by photogenerated hole to form chlorine $\left(\mathrm{Cl}_{2}\right)$ occurs before the oxidation of water as given by equation $(4)^{18} \cdot \mathrm{Cl}_{2}$ is in the disproportionation equilibrium with hypochlorous acid ( $\mathrm{HClO}$ ), as given by equation (5), where the population of $\mathrm{Cl}_{2}$ and $\mathrm{HClO}$ varies depending on the $\mathrm{pH}$ the solution and $\mathrm{Cl}_{2}$ is a major component under an acidic solution below $\mathrm{pH} 3$ (refs 18,19). Second, $\mathrm{HClO}$ is decomposed to $\mathrm{O}_{2}$ and $\mathrm{Cl}^{-}$under solar irradiation, as given by equation $(6)^{20}$. Thus, the overall reaction of the water oxidation assisted by $\mathrm{Cl}^{-}$is given by equation (1). Indeed, the ultraviolet-visible absorption spectrum

$$
\begin{gathered}
2 \mathrm{Cl}^{-}+2 \mathrm{~h}^{+} \stackrel{h v}{\longrightarrow} \mathrm{Cl}_{2} \\
\mathrm{Cl}_{2}+\mathrm{H}_{2} \mathrm{O} \rightleftarrows \mathrm{HClO}+\mathrm{H}^{+}+\mathrm{Cl}^{-} \\
2 \mathrm{HClO} \stackrel{h v}{\longrightarrow} \mathrm{O}_{2}+2 \mathrm{H}^{+}+2 \mathrm{Cl}^{-}
\end{gathered}
$$

of the anode cell solution after the photocatalytic reaction for $24 \mathrm{~h}$ exhibited the absorption band around at $231 \mathrm{~nm}$, which is identical to the spectrum of a standard $\mathrm{HClO} / \mathrm{Cl}_{2}$ solution below pH 3 (Supplementary Fig. 3$)^{19}$. The amount of $\mathrm{O}_{2}$ evolved in seawater in anode cell after $1 \mathrm{~h}(12.7 \mu \mathrm{mol})$ was more than three times larger than that in water $(3.7 \mu \mathrm{mol})$ as shown in Supplementary Fig. 4. Thus, the enhancement of photocatalytic production of $\mathrm{H}_{2} \mathrm{O}_{2}$ in seawater (Fig. 2) results from the photocatalytic oxidation of $\mathrm{Cl}^{-}$in seawater.

The effects of $\mathrm{Cl}^{-}$on the catalytic performance of $\mathrm{m}-\mathrm{WO}_{3} / \mathrm{FTO}$ and $\mathrm{Co}^{\mathrm{II}}(\mathrm{Ch}) / \mathrm{CP}$ were also investigated by using a photoelectrochemical cell with three electrode configuration. The current-potential $(I-V)$ curves of $\mathrm{m}-\mathrm{WO}_{3} / \mathrm{FTO}$ under simulated 1 sun illumination and dark are shown in Fig. 3a. The onset of photocurrent for the oxidation of water was observed at $0.2 \mathrm{~V}$ (versus saturated calomel electrode (SCE)) in water ( $\mathrm{pH} 1.3)$, which corresponds to the $110 \mathrm{mV}$ of overpotential with respect to the value of flat band potential of $\mathrm{WO}_{3}(0.09 \mathrm{~V}$ versus SCE at $\mathrm{pH}$
$1.3)^{22}$. This overpotential is required as a driving force for the migration of the photogenerated electron from conduction band of $\mathrm{WO}_{3}$ to FTO electrode. When the photocatalysis measurements of $\mathrm{m}-\mathrm{WO}_{3} / \mathrm{FTO}$ were performed under the same conditions in seawater instead of pure water, about four times larger photocurrent at $0.3 \mathrm{~V}$ (versus SCE) than that in water together with the negative shift of onset potential from $0.2 \mathrm{~V}$ (versus SCE) to $0.1 \mathrm{~V}$ (versus SCE) was observed (Fig. 3a). In addition, the stability of a photocurrent obtained by applying $0.3 \mathrm{~V}$ (versus SCE) was also improved as shown in Supplementary Fig. 5a. These improvements in the stability as well as the photocurrent in seawater can be explained by the efficient quenching of the photogenerated hole in VB by the oxidation of $\mathrm{Cl}^{-}$, as described above. These are consistent with the enhancement of photocatalytic production of $\mathrm{H}_{2} \mathrm{O}_{2}$ in seawater (Fig. 2). The Faradaic efficiencies in the photoelectrochemical water oxidation in water and in seawater were determined to be $77 \%$ and $93 \%$, respectively, from the simultaneous measurements of $\mathrm{O}_{2}$ evolution (Supplementary Fig. 5b). The effect of $\mathrm{Cl}^{-}$on the electrochemical property of $\mathrm{Co}^{\mathrm{II}}(\mathrm{Ch}) / \mathrm{CP}$ was also studied by measuring cyclic voltammograms using the three-electrode electrochemical cell. The addition of tetra- $n$-butylammonium chloride $(0.1 \mathrm{M})$ to a $\mathrm{N}_{2}$-saturated $\mathrm{PhCN}$ solution containing $\mathrm{Co}^{\mathrm{II}}(\mathrm{Ch})(1 \mathrm{mM})$ and tetra- $n$-butylammonium hexafluorophosphate $\left(\mathrm{TBAPF}_{6} ; 0.1 \mathrm{M}\right)$ resulted in the large negative shift of the redox potential for $\left[\mathrm{Co}^{\mathrm{III}}(\mathrm{Ch})\right]^{+} / \mathrm{Co}^{\mathrm{II}}(\mathrm{Ch})$ from 0.37 to $0.01 \mathrm{~V}$ (versus SCE; Supplementary Fig. 6a,b). In addition, no catalytic current was obtained for the $\mathrm{O}_{2}$ reduction in the presence of $\mathrm{Cl}^{-}$in an $\mathrm{O}_{2}$-saturated $\mathrm{PhCN}$ solution containing $\mathrm{HClO}_{4}(10 \mathrm{mM})$ as a proton source (Supplementary Fig. 6c), suggesting that $\mathrm{Cl}^{-}$inhibits electron transfer from $\mathrm{Co}^{\mathrm{II}}(\mathrm{Ch})$ to $\mathrm{O}_{2}$ because of the strong axial coordination of $\mathrm{Cl}^{-}$to the reaction centre of $\mathrm{Co}^{\mathrm{II}}(\mathrm{Ch})$ to form 5- or 6-coordinated inactive species. In contrast, the catalytic current for the $\mathrm{O}_{2}$ reduction with $\mathrm{Co}^{\mathrm{II}}(\mathrm{Ch}) / \mathrm{CP}$ measured in seawater $(\mathrm{pH} 1.3)$ appeared at ca $0.34 \mathrm{~V}$ (versus SCE), which is virtually the same onset potential and catalytic current measured in water ( $\mathrm{pH} 1.3)$, as shown in Fig. 3b. This result indicates that the coordination of $\mathrm{Cl}^{-}$to $\mathrm{Co}^{\mathrm{II}}(\mathrm{Ch})$ adsorbed on the electrode surface in an aqueous solution is negligibly weak as compared with that in $\mathrm{PhCN}^{23}$. Hence, the enhancement of photocatalytic production of $\mathrm{H}_{2} \mathrm{O}_{2}$ is mainly derived from the acceleration of water oxidation at the photoanode. The predicted operating current of the two-compartment photoelectrochemical cell was defined from the intersection of cyclic voltammograms of $\mathrm{Co}^{\mathrm{II}}(\mathrm{Ch}) / \mathrm{CP}$ and $I-V$ curves of the $\mathrm{m}-\mathrm{WO}_{3} / \mathrm{FTO}$ photoanode, giving a value of $0.5 \mathrm{~mA}$ at $0.32 \mathrm{~V}$ (versus SCE) in water and $1.3 \mathrm{~mA}$ at $0.29 \mathrm{~V}$ (versus SCE) in seawater, respectively (Fig. 3c).

The effect of illumination intensity on the photocatalytic production of $\mathrm{H}_{2} \mathrm{O}_{2}$ was examined as shown in Supplementary Fig. $7 \mathrm{a}$, where the produced amount of $\mathrm{H}_{2} \mathrm{O}_{2}$ increased in proportion to the intensity of the illumination. The solar energy conversion efficiency for the photocatalytic production of $\mathrm{H}_{2} \mathrm{O}_{2}$ in seawater was determined to be $0.55 \%$ under simulated 1 sun illumination. The best solar energy conversion efficiency was determined to be $0.94 \%$ when illumination intensity was reduced to 0.1 sun (Supplementary Fig. 7b). This efficiency exceeds that of swichgrass $(0.2 \%)$, which has been considered as a promising crop for biomass fuel ${ }^{24}$, and also the value in the onecompartment cell $(0.25 \%)^{4}$. A much higher solar-to-hydrogen efficiency of $12.3 \%$ has recently been achieved by perovskite photovoltaics-based electrolysis ${ }^{2}$. However, the storage of hydrogen has still been a quite difficult issue, because hydrogen is a gas having a low volumetric energy density. In this contrast, in our system, the produced hydrogen peroxide in seawater can be used directly as a fuel in an $\mathrm{H}_{2} \mathrm{O}_{2}$ fuel cell. 
a

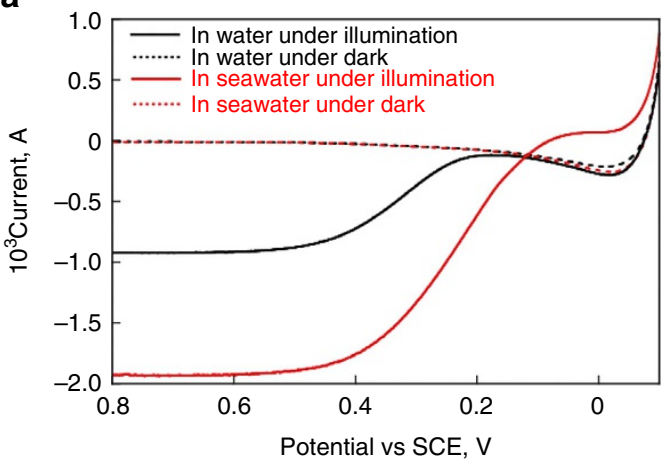

b

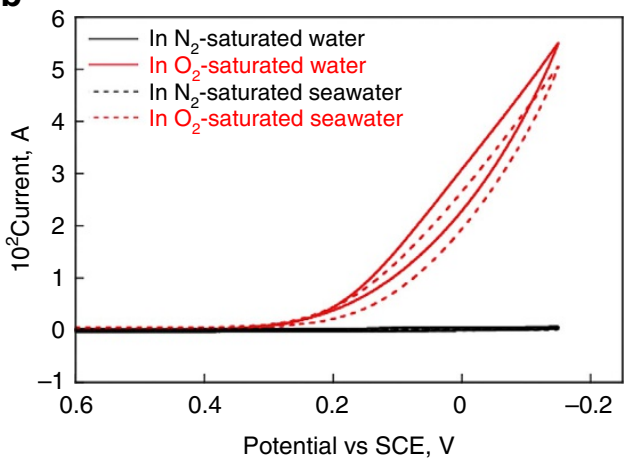

C

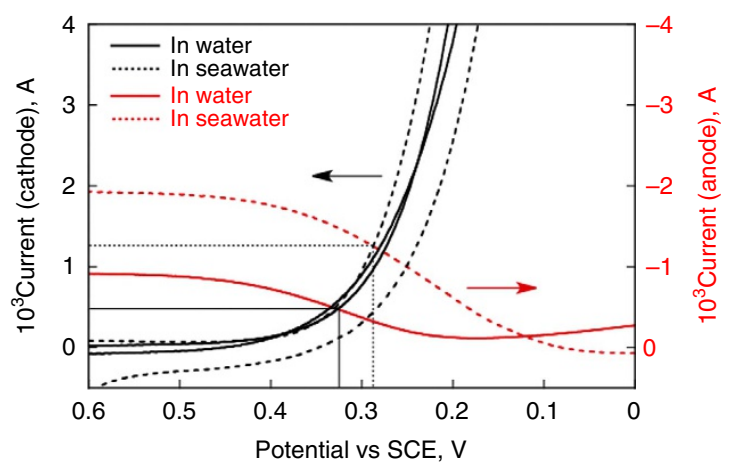

Figure 3 | Photoelectrochemical performance of $\mathbf{m}-\mathbf{W O}_{3} / \mathbf{F T O}$ and electrochemical performance of $\mathbf{C o}{ }^{\text {Il }}(\mathbf{C h}) / \mathbf{C P}$. (a) $I-V$ curves of $\mathrm{m}-\mathrm{WO} \mathrm{O}_{3} / \mathrm{FTO}$ photoanode in $\mathrm{pH} 1.3$ water (black solid) and in $\mathrm{pH} 1.3$ seawater (red solid) under simulated 1 sun (AM 1.5G) illumination. I-V curves under dark are shown as dashed lines with the same colour definition. Sweep rate: $10 \mathrm{mVs}^{-1}$. (b) Cyclic voltammograms of $\mathrm{Co}^{\|}(\mathrm{Ch}) / \mathrm{CP}$ in a $\mathrm{N}_{2}$-saturated pH 1.3 water (black solid) and an $\mathrm{O}_{2}$-saturated $\mathrm{pH} 1.3$ water (red solid). The dashed lines show the cyclic voltammograms of $\mathrm{Co}$ "l $(\mathrm{Ch}) / \mathrm{CP}$ recorded in $\mathrm{pH} 1.3$ seawater. Sweep rate: $20 \mathrm{mVs}^{-1}$. (c) Cyclic voltammograms of $\mathrm{Co}^{\prime \prime}(\mathrm{Ch}) / \mathrm{CP}$ in $\mathrm{O}_{2}$-saturated $\mathrm{pH} 1.3$ solutions (black) and $I-V$ curves of $\mathrm{m}-\mathrm{WO}_{3} / \mathrm{FTO}$ photoanode in $\mathrm{pH} 1.3$ solutions (red) under simulated 1 sun (AM 1.5G) illumination.

$\mathrm{H}_{2} \mathrm{O}_{2}$ fuel cell. Finally, the chemical energy of $\mathrm{H}_{2} \mathrm{O}_{2}$ produced by the photocatalytic reaction was converted to electrical energy through a $\mathrm{H}_{2} \mathrm{O}_{2}$ fuel cell composed of a polynuclear cyanide complexes, $\mathrm{Fe}_{3}{ }_{3}{ }_{3}\left[\mathrm{CO}^{\mathrm{II}}(\mathrm{CN})_{6}\right]_{2}$, modified carbon cloth cathode and a nickel mesh anode in a one-compartment cell ${ }^{10}$. The reaction solution (seawater, $\mathrm{pH}$ 1.3) containing ca $48 \mathrm{mM}$ of $\mathrm{H}_{2} \mathrm{O}_{2}$ in cathode was transferred to the $\mathrm{H}_{2} \mathrm{O}_{2}$ fuel cell. The obtained potential and power density depending on the current density are shown in Fig. 4 . The cell has the open-circuit potential and the maximum power density of $0.78 \mathrm{~V}$ and $1.6 \mathrm{~mW} \mathrm{~cm}^{-2}$, respectively. These values agree with those obtained from the $\mathrm{H}_{2} \mathrm{O}_{2}$ fuel cell using an aqueous solution $(\mathrm{pH}$ 1.0) containing authentic $\mathrm{H}_{2} \mathrm{O}_{2}(50 \mathrm{mM})$ and $\mathrm{NaCl}(1.0 \mathrm{M})$ as a supporting electrolyte (Supplementary Fig. 8). In addition, the energy conversion efficiency of the $\mathrm{H}_{2} \mathrm{O}_{2}$ fuel cell was determined to be ca $50 \%$ by the measurement of output energy as electrical energy versus consumed chemical energy $\mathrm{H}_{2} \mathrm{O}_{2}$ gas, which is comparable to the efficiency of an $\mathrm{H}_{2}$ fuel cell (Supplementary Figs 9 and 10). Thus, the solar-to-electricity conversion efficiency of the total system is estimated to be ca $0.28 \%(0.55 \times 50 \%)$, which is still much lower in contrast to the conventional solar-toelectricity device such as photovoltaic cells. However, there are still many things to do in the one-compartment $\mathrm{H}_{2} \mathrm{O}_{2}$ fuel cells including better anode materials to improve the performance, because the one compartment cell without membrane and use of an aqueous solution of $\mathrm{H}_{2} \mathrm{O}_{2}$ have significant advantages as compared with $\mathrm{H}_{2}$ fuel cells. The production of chemical energy utilizing solar energy and its conversion to electrical energy based on $\mathrm{H}_{2} \mathrm{O}_{2}$ in seawater can provide practical solution to the construction of an ideal energy-sustainable society using seawater, which is the most earth-abundant resource.

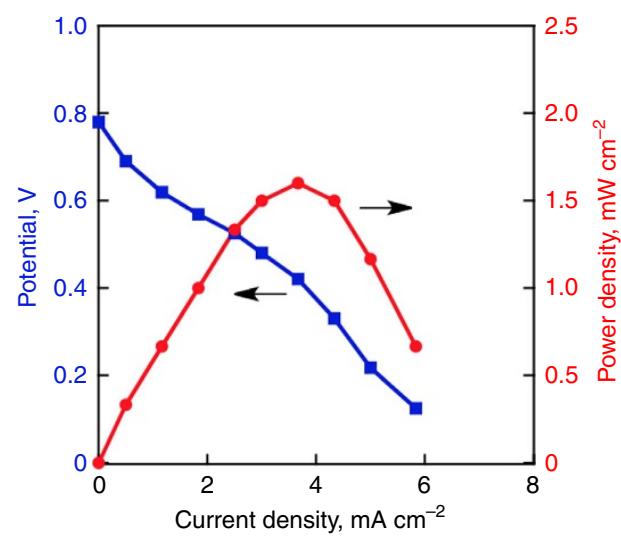

Figure 4 | Generation of electrical energy in the one-compartment $\mathrm{H}_{2} \mathrm{O}_{2}$ fuel cell. $I-V$ (blue) and $I-P\left(\right.$ red) curves of the one-compartment $\mathrm{H}_{2} \mathrm{O}_{2}$ fuel cell with a $\mathrm{Ni}$ mesh anode and $\mathrm{Fe}_{3}{ }_{3}\left[\mathrm{Co}{ }^{\prime \prime \prime}(\mathrm{CN})_{6}\right]_{2}$ /carbon cloth cathode in the reaction solution containing $\mathrm{H}_{2} \mathrm{O}_{2}(47.9 \mathrm{mM})$ produced by photocatalytic reaction in seawater as shown in Fig. 2 (blue circle).

\section{Methods}

Materials. Chemicals were purchased from commercial sources and used without further purification, unless otherwise noted. Benzonitrile (PhCN) used for spectroscopic and electrochemical measurements was distilled over phosphorus pentoxide before use ${ }^{25}$. Potassium hexacyanoferrate(III) $\left(\mathrm{K}_{3}\left[\mathrm{Fe}(\mathrm{CN})_{6}\right]\right)$ and acetylacetone ( $\geqq 99 \%$ ) were purchased from Wako Pure Chemical Industries Ltd., Tungsten hexachloride ( $\mathrm{WCl}_{6}$, $\geqq 95 \%$ ) was purchased from Nacalai Tesque. Scandium(III) nitrate tetrahydrate was purchased from Mitsuwa Chemicals. Potassium hexacyanocobaltate $\left(\mathrm{K}_{3}\left[\mathrm{Co}^{\mathrm{III}}(\mathrm{CN})_{6}\right]\right.$, $\left.\geqq 99.9 \%\right)$ was supplied by Stream Chemicals. Red sea salt was supplied by Red Sea. Oxo[5,10,15,20-tetra 
(4-pyridyl)porphinato]titanium(IV) ([TiO(tpyp)]) was purchased from Tokyo Chemical Industry Co., Ltd. (TCI). Pluronic P-123, Triton X-100, Nafion perfluorinated ion exchange resin solution, Nafion perfluorinated membrane (Nafion 117) were received from Aldrich Chemical Co. CP electrode (EC-TP1-060T produced by Toray Industry Inc.) was obtained from Toyo Co. Glass slides coated with FTO (transmittance, 83.6\%) were supplied by Aldrich Chemicals Co. and cut by Asahi Glass Co., Ltd. Tetra- $n$-butylammonium hexafluorophosphate $\left(\mathrm{TBAPF}_{6}\right.$ ) purchased from Wako Pure Chemical Industries, Ltd. was twice recrystallized from ethanol and dried in vacuo before use. Purified water was provided by a Millipore Milli-Q water purification system (Millipore, Direct-Q $3 \mathrm{UV}$ ) with an electronic conductance of $18.2 \mathrm{M} \Omega \mathrm{cm}$. Cobalt chlorin complex $\left[\mathrm{Co}{ }^{\mathrm{II}}(\mathrm{Ch})\right]$, mesoporous $\mathrm{WO}_{3}\left(\mathrm{~m}-\mathrm{WO}_{3}\right)$ and polynuclear cyanide complex $\left(\mathrm{Fe}_{3} \mathrm{II}_{3}\left[\mathrm{Co}^{\mathrm{III}}(\mathrm{CN})_{6}\right]_{2}\right)$ were synthesized according to the literature procedure (vide infra).

Preparation of Co"l(Ch)/CP electrode. $\mathrm{Co}^{\mathrm{II}}(\mathrm{Ch}) / \mathrm{CP}$ electrode was prepared by an MeCN solution $(1 \mathrm{ml})$ of $\mathrm{Co}^{\mathrm{II}}(\mathrm{Ch})(0.3 \mathrm{mM})$, MWCNT $(0.63 \mathrm{mg})$ and $5 \%$ Nafion $(12 \mu \mathrm{l})$. For each experiment, the mixture was sonicated for $20 \mathrm{~min}$ and then a $50 \mu \mathrm{l}$ of the mixture was applied on the both side of surface of a CP with a $3.0 \mathrm{~cm}^{2}$ area by drop-casting and allowed to evaporate to afford a film containing a MWCNT loading of $50 \mu \mathrm{g} \mathrm{cm}^{-2}$ and a catalyst loading of $30 \mathrm{nmol}$.

Preparation of $\mathbf{m}-\mathrm{WO}_{3} / \mathrm{FTO}$ electrode. First, FTO glasses were cleaned before use by immersing into an $\mathrm{MeOH} / \mathrm{HCl}(1 / 1(\mathrm{v} / \mathrm{v}))$ solution for $30 \mathrm{~min}$ and washed by purified water. The resulting FTO glasses were hydroxylated in $\mathrm{H}_{2} \mathrm{SO}_{4}$ for $2 \mathrm{~h}$ and then boiled in purified water for 30 min with subsequent drying under $\mathrm{N}_{2}$ (ref. 26). $\mathrm{m}-\mathrm{WO}_{3} / \mathrm{FTO}$ electrode was prepared by a solution consisting of $1 \mathrm{ml}$ of water containing $50 \mathrm{mg}$ of $\mathrm{m}-\mathrm{WO}_{3}$ and acetyl acetone $(30 \mu \mathrm{l})$ and 1 drop of Triton $\mathrm{X}-100$. The mixture was sonicated for $5 \mathrm{~min}$ and then a $50 \mu \mathrm{l}$ drop was applied on the surface of FTO electrode with a $2.5 \mathrm{~cm}^{2}$ area and allowed to evaporate to afford a thin film. The resulting electrode was annealed to form crystalline $\mathrm{m}-\mathrm{WO}_{3}$ at $400^{\circ} \mathrm{C}$ with ramping rate of $2^{\circ} \mathrm{C} \mathrm{min}^{-1}$ (held at $400^{\circ} \mathrm{C}$ for $2 \mathrm{~h}$ ) under air to remove surfactant species. The combustion of residual surfactant was confirmed by thermal gravimetric-differential thermal analysis (TG-DTA) of $\mathrm{m}-\mathrm{WO}_{3}$ dispersion prepared above (Supplementary Fig. 11). The exothermic current peak along with weight loss observed at around $180^{\circ} \mathrm{C}$ was disappeared after the annealing at $400^{\circ} \mathrm{C}$. The morphology of obtained $\mathrm{m}-\mathrm{WO}_{3} / \mathrm{FTO}$ was observed by scanning electron microscope (SEM), as shown in Supplementary Fig. 12. The mesoporous structure of $\mathrm{m}-\mathrm{WO}_{3}$ was confirmed by $\mathrm{N}_{2}$ adsorption-desorption isotherm measurements (Supplementary Fig. 13). The measurements performed at $77 \mathrm{~K}$ revealed a type IV isotherm ${ }^{27}$, clearly indicating the presence of mesopores. The Brunauer-Emmett-Teller surface area of $\mathrm{m}-\mathrm{WO}_{3}$ was as high as $21 \mathrm{~m}^{2} \mathrm{~g}^{-1}$ (Supplementary Fig. 13a). The size of the mesopores was determined to be $8 \mathrm{~nm}$ by Barrett-Joyner-Halenda plot (Supplementary Fig. 13b)

Preparation of seawater. The seawater was prepared by dissolving $33.4 \mathrm{~g}$ of red sea salt in 11 of water to form a solution containing ca $550 \mathrm{mM}$ of $\mathrm{NaCl}$.

Characterization of $\mathbf{m}-\mathbf{W O}_{3} / \mathbf{F T O}$. TG/DTA data were performed on an SII TG/DTA 7,200 instrument. A sample (ca10 mg) was loaded into an Al pan and heated from $25^{\circ} \mathrm{C}$ to $600^{\circ} \mathrm{C}$ with a ramping rate of $2^{\circ} \mathrm{C} \mathrm{min}^{-1}$ under $\mathrm{N}_{2}$. A certain amount of $\gamma-\mathrm{Al}_{2} \mathrm{O}_{3}$ was used as a reference for DTA measurements. Nitrogen-adsorption/desorption measurements were performed at $77 \mathrm{~K}$ on a Belsorp-mini (BEL Japan, Inc.) within a relative pressure range from 0.01 to $101.3 \mathrm{kPa}$. A sample mass of ca $100 \mathrm{mg}$ used for adsorption analysis was pretreated at $150^{\circ} \mathrm{C}$ for $2 \mathrm{~h}$ under vacuum conditions and kept in $\mathrm{N}_{2}$ atmosphere until $\mathrm{N}_{2}$-adsorption measurements. The resulting sample was exposed to a mixed gas of $\mathrm{He}$ and $\mathrm{N}_{2}$ with a programmed ratio and adsorbed amount of $\mathrm{N}_{2}$ was calculated from the change of pressure in a cell after reaching equilibrium (at least $5 \mathrm{~min}$ ). Powder X-ray diffraction patterns were recorded on a Rigaku MiniFlex 600. Incident X-ray radiation was produced by a Cu X-ray tube, operating at $40 \mathrm{kV}$ and $15 \mathrm{~mA}$ with $\mathrm{Cu} \mathrm{K} \alpha$ radiation $(\lambda=1.54 \AA)$. The scan rate was $1^{\circ} \mathrm{min}^{-1}$ from $2 \theta=10-70^{\circ}$. SEM images of particles were observed by a FE-SEM (JSM-6320F or JSM-6701F) operating at $10 \mathrm{kV}$.

Electrochemical measurements. Cyclic voltammetry measurements were performed on an ALS 630B electrochemical analyser. Effects of $\mathrm{Cl}^{-}$on $\mathrm{Co}^{\mathrm{II}}(\mathrm{Ch})$ was investigated in a $\mathrm{N}_{2}$ - or $\mathrm{O}_{2}$-saturated $\mathrm{PhCN}$ solution containing $0.10 \mathrm{M} \mathrm{TBAPF}_{6}$ as a supporting electrolyte at $298 \mathrm{~K}$ using a conventional three-electrode cell with a glassy carbon (GC) working electrode (surface area of $0.3 \mathrm{~mm}^{2}$ ) and a platinum wire $(\mathrm{Pt})$ as the counter electrode. The GC working electrode was routinely polished with polishing alumina suspension and rinsed with acetone before use. The potentials were measured with respect to the $\mathrm{Ag} / \mathrm{AgNO}_{3}\left(1.0 \times 10^{-2} \mathrm{M}\right)$ reference electrode. All potentials (versus $\mathrm{Ag} / \mathrm{AgNO}_{3}$ ) were converted to values versus SCE by adding $0.29 \mathrm{~V}$ (ref. 28). Redox potentials were determined using the relation $E_{1 / 2}=\left(E_{\mathrm{pa}}+E_{\mathrm{pc}}\right) / 2$.

Electrochemical performance of $\mathrm{Co}^{\mathrm{II}}(\mathrm{Ch})$ deposited on $\mathrm{CP}$ electrode for the catalytic $\mathrm{O}_{2}$ reduction was evaluated in a $\mathrm{N}_{2}$ - or $\mathrm{O}_{2}$-saturated aqueous $\mathrm{HClO}_{4}$
( $\mathrm{pH}$ 1.3) solution containing $\mathrm{NaClO}_{4}(0.1 \mathrm{M})$ as a supporting electrolyte and in $\mathrm{N}_{2}$ - or $\mathrm{O}_{2}$-saturated seawater containing $\mathrm{HClO}_{4}(\mathrm{pH} 1.3)$ and $\mathrm{NaClO}_{4}(0.1 \mathrm{M})$ at $298 \mathrm{~K}$ using a conventional three-electrode cell consisting of $\mathrm{Co}^{\mathrm{II}}(\mathrm{Ch}) / \mathrm{CP}$ as a working electrode and a platinum coil as the counter electrode. All the photoelectrochemical and electrochemical measurements in aqueous solutions were conducted using a reference SCE and all results in this work are presented against the SCE. The conversion of potentials versus SCE to versus normal hydrogen electrode (NHE) was performed according to the following equation (7).

$$
\begin{aligned}
E(\text { vs SCE at measured } \mathrm{pH})= & E(\text { vs NHE at } \mathrm{pH} 0)-0.241 \mathrm{~V} \\
& -0.059 \mathrm{~V} \times \mathrm{pH}
\end{aligned}
$$

The superior performance of $\mathrm{Co}^{\mathrm{II}}(\mathrm{Ch}) / \mathrm{CP}$ in an aqueous solution was confirmed by the comparison with cobalt octaethylporphyrin $\left(\mathrm{Co}^{\mathrm{II}}(\mathrm{OEP})\right)$, which is commonly used as an electrocatalyst for the $\mathrm{O}_{2}$ reduction, modified CP $\left(\mathrm{Co}^{\mathrm{II}}(\mathrm{OEP}) / \mathrm{CP}\right)$, as shown in Supplementary Fig. 14.

The RRDE measurements were carried out using a BAS RRDE-3A rotator linked to an ALS 730D electrochemical analyser. A three-electrode cell $(100 \mathrm{ml})$ was employed with the RRDE consisting of a platinum ring $(\mathrm{Pt})$ electrode and a GC disk electrode, platinum coil (Pt) as a counter electrode and SCE as a reference electrode. The voltammograms were measured in an $\mathrm{O}_{2}$-saturated aqueous $\mathrm{HClO}_{4}$ solution ( $\mathrm{pH} \mathrm{1.3)}$ containing $\mathrm{NaClO}_{4}(0.1 \mathrm{M})$ at $5 \mathrm{mV} \mathrm{s}^{-1}$ with various rotating rates $(100,300,600,900,1,200,1,500,2,000,2,500,3,000,3,500,4,000$ and 4,500 r.p.m.). A RRDE for the investigation of transferred electrons during catalytic $\mathrm{O}_{2}$ reduction with $\mathrm{Co}^{\mathrm{II}}(\mathrm{Ch}) / \mathrm{CP}$ was performed by the modification of GC disk electrode with a thin film of $\mathrm{Co}^{\mathrm{II}}(\mathrm{Ch})$. The thin film was prepared by a solution consisting of $\mathrm{MeCN}(1 \mathrm{ml})$ containing $\mathrm{Co}^{\mathrm{II}}(\mathrm{Ch})(0.3 \mathrm{mM})$, MWCNT $(1.26 \mathrm{mg})$ and $5 \%$ Nafion $(12 \mu \mathrm{l})$. For each experiment, the mixture was sonicated for $20 \mathrm{~min}$ and then a 10- $\mu$ l drop was applied on the surface of a polished GC disk electrode and allowed to evaporate to afford a thin film containing a MWCNT loading of $100 \mu \mathrm{g} \mathrm{cm}^{-2}$ and a catalyst loading of $3 \mathrm{nmol}$.

The number of transferred electrons $(n)$ is determined by following equation $n=4 I_{\mathrm{D}} /\left(I_{\mathrm{D}}+I_{\mathrm{R}} / N\right)$, where $I_{\mathrm{D}}$ is the faradic current at the disk electrode, $I_{\mathrm{R}}$ is the faradic current at the ring electrode, and $N$ is the collection efficiency of the RRDE The $N$ value is measured using an aqueous solution of $\mathrm{K}_{3}\left[\mathrm{Fe}^{\mathrm{III}}(\mathrm{CN})_{6}\right](2 \mathrm{mM})$ as a standard one-electron redox couple $\left(\left[\mathrm{Fe}^{\mathrm{III}}(\mathrm{CN})_{6}\right]^{3-} /\left[\mathrm{Fe}^{\mathrm{II}}(\mathrm{CN})_{6}\right]^{4-}\right)$ in the presence of $\mathrm{KNO}_{3}(0.5 \mathrm{M})$ and is determined to be $N=0.37$ when the GC disk electrode of RRDE is loaded with the same amount of MWCNT $\left(100 \mu \mathrm{g} \mathrm{cm}^{-2}\right)$ as used above (Supplementary Fig. 15).

Photoelectrochemical measurements. Photoelectrochemical measurements were performed in a home-made quartz cell (light path length $=1 \mathrm{~cm}$ ) composed of the as prepared $\mathrm{m}-\mathrm{WO}_{3} / \mathrm{FTO}$ electrode, a platinum coil counter electrode, and a $\mathrm{SCE}$ reference electrode in an Ar-saturated aqueous solution ( $8 \mathrm{ml}$ ) containing $\mathrm{HClO}_{4}$ (pH 1.3) and $0.1 \mathrm{M}$ of $\mathrm{NaClO}_{4}$ at $298 \mathrm{~K}$ (Supplementary Fig. 16a). The photoanode was illuminated from the back side of FTO electrode (FTO/electrolyte interface) with a solar simulator (HAL-320, Asahi Spectra Co., Ltd.), where the light intensity was adjusted at $100 \mathrm{~mW} \mathrm{~cm}^{-2}$ (AM1.5G) at the sample position by a 1SUN checker (CS-20, Asahi Spectra Co., Ltd.). The Faradaic efficiency for $\mathrm{O}_{2}$ evolution was determined by following equation (8), where $F$ denotes Faradaic constant $\left(9.65 \times 10^{4} \mathrm{C} \mathrm{mol}^{-1}\right)$.

The Faradaic efficiency for $\mathrm{O}_{2}$ evolution (\%)

$$
=\frac{\left[\text { Amount of evolved } \mathrm{O}_{2}, \mathrm{~mol}\right]}{\text { Total charge passed } / 4 \times F, \mathrm{~mol}} \times 100
$$

Photocatalytic production of $\mathbf{H}_{\mathbf{2}} \mathbf{O}_{\mathbf{2}}$. Photocatalytic production of $\mathrm{H}_{2} \mathrm{O}_{2}$ was performed in a quartz anode cell (light path length $=1 \mathrm{~cm}$ ) connected with a pyrex cathode cell through a Nafion membrane (Supplementary Fig. 16b). The anode cell consists of the as prepared $\mathrm{m}-\mathrm{WO}_{3} / \mathrm{FTO}$ photoanode for the water oxidation in an Ar-saturated aqueous solution $(8 \mathrm{ml})$ containing $\mathrm{HClO}_{4}(\mathrm{pH} 1.3)$ and $0.1 \mathrm{M}$ of $\mathrm{NaClO}_{4}$. The cathode cell is composed of the as prepared $\mathrm{Co}^{\mathrm{II}}(\mathrm{Ch}) / \mathrm{CP}$ cathode for the $\mathrm{O}_{2}$ reduction in an $\mathrm{O}_{2}$-saturated aqueous solution $(10 \mathrm{ml})$ containing $\mathrm{HClO}_{4}$ ( $\mathrm{pH} 1.3$ ) and $0.1 \mathrm{M}$ of $\mathrm{NaClO}_{4}$ at $298 \mathrm{~K}$. These two electrodes were connected each other with alligator clips and copper wire as an external circuit. The photoanode was illuminated from the back side of the FTO electrode with the solar simulator (HAL-320, Asahi Spectra Co., Ltd.), where the light intensity was adjusted at $100 \mathrm{~mW} \mathrm{~cm}^{-2}$ (AM1.5G) at the sample position by the 1SUN checker (CS-20, Asahi Spectra Co., Ltd.). The anode and cathode solution was saturated by continuous bubbling with argon and oxygen gas for $30 \mathrm{~min}$, respectively, before the photocatalytic reaction. The $\mathrm{O}_{2}$ bubbling was continued during the photocatalytic reaction. The cathode cell was kept in dark to prevent the decomposition of produced $\mathrm{H}_{2} \mathrm{O}_{2}$ by ultraviolet-light irradiation during photocatalytic reaction. The amount of produced $\mathrm{H}_{2} \mathrm{O}_{2}$ was determined by spectroscopic titration with an acidic solution of $\left[\mathrm{TiO}\left(\text { tpypH }_{4}\right)\right]^{4+}$ complex (Ti-TPyP reagent $)^{29}$. The Ti-TPyP reagent was prepared by dissolving $3.40 \mathrm{mg}$ of the [TiO(tpyp)] complex in $100 \mathrm{ml}$ of hydrochloric acid $(50 \mathrm{mM})$. A small portion of the reaction solution was sampled and diluted with water depending on the concentration of produced $\mathrm{H}_{2} \mathrm{O}_{2}$. To $0.25 \mathrm{ml}$ of $4.8 \mathrm{M} \mathrm{HClO}_{4}$ and $0.25 \mathrm{ml}$ of the Ti-TPyP reagent, a diluted sample was added. The mixed solution was then allowed to stand for $5 \mathrm{~min}$ at room temperature. This sample solution was diluted to $2.5 \mathrm{ml}$ with water and used for the 
spectroscopic measurement. The absorbance at $\lambda=434 \mathrm{~nm}$ was measured by using a Hewlett Packard 8453 diode array spectrophotometer. A blank solution was prepared in a similar manner by adding distilled water instead of the sample solution to Ti-TPyP reagent in the same volume with its absorbance designated as $A_{\mathrm{B}}$. The difference in absorbance was determined as follows: $\Delta A_{434}=A_{\mathrm{B}}-A_{\mathrm{S}}$ Based on $\Delta A_{434}$ and the volume of the solution, the amount of $\mathrm{H}_{2} \mathrm{O}_{2}$ was determined (Supplementary Fig. 17).

Detection of $\mathbf{O}_{\mathbf{2}}$. The concentration of $\mathrm{O}_{2}$ in the anolyte was monitored during both photocatalytic production of $\mathrm{H}_{2} \mathrm{O}_{2}$ and photoelecrochemical measurements (vide supra) by using a fluorescence-based oxygen sensor (FOXY Fiber Optic Oxygen Sensor, Ocean Optics). The $\mathrm{O}_{2}$-sensing needle probe was installed in a gas-tight quartz anode cell filled with $8 \mathrm{ml}$ of a solution, which left $7 \mathrm{ml}$ of a headspace, through a rubber septum on the end of the cell. The solution and headspace were purged with argon gas for $30 \mathrm{~min}$ before measurements. Two-point calibration of the $\mathrm{O}_{2}$ sensor was performed against solutions (air, 20.9\% $\mathrm{O}_{2}$, and Ar, $0 \% \mathrm{O}_{2}$ ) used in each measurement. The amount of $\mathrm{O}_{2}$ leaked in the anode cell during measurements was determined under dark and subtracted from the data obtained under illumination. The amount of dissolved $\mathrm{O}_{2}$ in solutions was recorded as mole \%. The total amount $\mathrm{O}_{2}$ evolved in the anode cell was determined using Henry's Law and converted, using the ideal gas law, into $\mu \mathrm{mol}$.

Solar-to- $\mathrm{H}_{2} \mathrm{O}_{\mathbf{2}}$ energy conversion efficiency. Measurement of solar energy conversion efficiency of the photocatalytic production of $\mathrm{H}_{2} \mathrm{O}_{2}$ was carried out in a quartz anode cell (light path length $=1 \mathrm{~cm}$ ) connected with a pyrex cathode cell through a Nafion membrane as used in photocatalytic production of $\mathrm{H}_{2} \mathrm{O}_{2}$ as described above. The photoanodes were illuminated from back side of the FTO electrode with the solar simulator (HAL-320, Asahi Spectra Co., Ltd.), where the light intensity was adjusted at $10-100 \mathrm{~mW} \mathrm{~cm}^{-2}$ (AM1.5G) at the sample position by the 1SUN checker (CS-20, Asahi Spectra Co., Ltd.). The amount of produced $\mathrm{H}_{2} \mathrm{O}_{2}$ was determined by the titration with the Ti-TPyP reagent (vide supra). The solar energy conversion efficiency was determined by following equations ( 3 and 9), where output energy as $\mathrm{H}_{2} \mathrm{O}_{2}$ was calculated by

Solar Energy Conversion Efficiency (\%)

[Output energy as $\mathrm{H}_{2} \mathrm{O}_{2}$ ]

$=\overline{[\text { Energy density of incident solar light }] \times[\text { Irradiation area }]} \times 100$

$=\frac{[\text { Enthalpy change of equation }(\Delta H)] \times\left[\text { Produced amount of } \mathrm{H}_{2} \mathrm{O}_{2}\right]}{[\text { Energy density of incident solar light }] \times[\text { Irradiation area }]} \times 100$

the multiplication of enthalpy change $\left(\Delta H=98.3 \mathrm{~kJ} \mathrm{~mol}^{-1}\right)$ and the produced amount of $\mathrm{H}_{2} \mathrm{O}_{2}$ (the concentration of $\mathrm{H}_{2} \mathrm{O}_{2} \times$ volume of cathode solution $(10 \mathrm{ml}))$. Energy density of incident solar light was adjusted at $10-100 \mathrm{~mW} \mathrm{~cm}^{-2}$ (0.1-1 SUN, Air Mass 1.5 (AM1.5)) at the sample position for whole irradiation area $\left(2.5 \mathrm{~cm}^{2}\right)$ by the 1 SUN checker (CS-20, Asahi Spectra Co., Ltd.) at room temperature.

Spectroscopic measurements. Ultraviolet-visible spectroscopy was carried out on a Hewlett Packard 8453 diode array spectrophotometer at room temperature using quartz cell (light path length $=1.0 \mathrm{~cm}$ ).

$\mathbf{H}_{\mathbf{2}} \mathbf{O}_{2}$ fuel cell. $\mathrm{Fe}_{3}{ }_{3}\left[\mathrm{Co}^{\mathrm{III}}(\mathrm{CN})_{6}\right]_{2}$ was mounted onto a carbon cloth by drop-casting or by spraying a dispersion of $\mathrm{Fe}_{3}^{\mathrm{II}}\left[\mathrm{Co}^{\mathrm{III}}(\mathrm{CN})_{6}\right]_{2}$ in isopropanol with an airbrush (TAMIYA Spray-work HG). An aqueous solution of Nafion (0.2 wt.\%) was used to protect the film of $\mathrm{Fe}_{3}{ }_{3}\left[\mathrm{Co}^{\mathrm{III}}(\mathrm{CN})_{6}\right]_{2}$ on a carbon cloth. A Ni mesh $\left(150\right.$ mesh) and $\mathrm{Fe}^{\mathrm{II}}{ }_{3}\left[\mathrm{Co}^{\mathrm{III}}(\mathrm{CN})_{6}\right]_{2}$ that was mounted onto a carbon cloth were immersed in the solution of $\mathrm{H}_{2} \mathrm{O}_{2}$. The performance tests were conducted in a one-compartment cell with the reaction solution containing $\mathrm{H}_{2} \mathrm{O}_{2}$ produced by the photocatalytic reaction transferred from the cathode cell of the two-compartment cell system. The current and power values normalized by the geometric surface area of an electrode were recorded on an ALS 630B electrochemical analyser and KFM $2005 \mathrm{FC}$ impedance meter at $25^{\circ} \mathrm{C}$. The performance tests in solutions containing various concentrations of standard $\mathrm{H}_{2} \mathrm{O}_{2}, \mathrm{HClO}_{4}(\mathrm{pH} \mathrm{1})$ and $\mathrm{NaCl}(1.0 \mathrm{M})$ were performed for the control experiment (Supplementary Fig. 8).

Energy conversion efficiency of $\mathbf{H}_{2} \mathbf{O}_{\mathbf{2}}$ fuel cell. $\mathrm{Fe}_{3} \mathrm{II}_{3}\left[\mathrm{Co}^{\mathrm{III}}(\mathrm{CN})_{6}\right]_{2} /$ carbon cloth and $\mathrm{Ni}$ mesh electrodes were prepared as noted above. Each electrode was connected with Pt wire and protected by PP (polypropylene) sheet to avoid electrical short circuit. The performance tests were conducted in a well-sealed one-compartment cell with a rubber septum (Supplementary Fig. 9). The reaction solution containing $\mathrm{H}_{2} \mathrm{O}_{2}(0.3 \mathrm{M}), \mathrm{NaCl}(1.0 \mathrm{M})$ and $\mathrm{Sc}\left(\mathrm{NO}_{3}\right)_{3} \bullet 4 \mathrm{H}_{2} \mathrm{O}(0.1 \mathrm{M})^{10}$ and the headspace $(6.5 \mathrm{ml})$ of the one-compartment cell were purged separately with argon gas for $30 \mathrm{~min}$ before measurements. After the argon-saturated reaction solution was transferred to the one-compartment cell using gas-tight syringe, cell voltage, applying constant current of $3.3 \mathrm{~mA}$, was recorded on a KFM 2005 FC impedance meter at $25^{\circ} \mathrm{C}$. The amount of evolved $\mathrm{O}_{2}$ gas in the headspace of one-compartment cell was quantified by a Shimadzu GC-17A gas chromatograph
(Ar carrier, a capillary column with molecular sieves (Agilent Technologies, $19095 \mathrm{PMS} 0,30 \mathrm{~m} \times 0.53 \mathrm{~mm}$ ) at $313 \mathrm{~K}$ ) equipped with a thermal conductivity detector. The energy conversion efficiency of $\mathrm{H}_{2} \mathrm{O}_{2}$ fuel cell was determined by following equations (3) and (10), where consumed chemical energy as $\mathrm{H}_{2} \mathrm{O}_{2}$ was calculated by the multiplication of enthalpy change $\left(\Delta H=-98.3 \mathrm{~kJ} \mathrm{~mol}^{-1}\right)$ and twice of the produced amount of $\mathrm{O}_{2}$ (Supplementary Fig. 10).

Energy Conversion Efficiency of $\mathrm{H}_{2} \mathrm{O}_{2}$ Fuel Cell (\%)

$$
\begin{aligned}
& =\frac{[\text { Output energy as electrical energy }]}{\left[\text { Consumed chemical energy as } \mathrm{H}_{2} \mathrm{O}_{2}\right]} \times 100 \\
& =\frac{[\text { Cell voltage }] \times[\text { Current }] \times[\text { Reaction time }]}{[\text { Enthalpy change of equation }(\Delta H)] \times\left[\text { Produced amount of } \mathrm{O}_{2}\right] \times 2} \times 100
\end{aligned}
$$

\section{References}

1. Faunce, T. A. et al. Energy and environment policy case for a global project on artificial photosynthesis. Energy Environ. Sci. 6, 695-698 (2013).

2. Luo, J. et al. Water photolysis at $12.3 \%$ efficiency via perovskite photovoltaics and Earth-abundant catalysts. Science 345, 1593-1596 (2014).

3. Maeda, K., Higashi, M., Lu, D., Abe, R. \& Domen, K. Efficient nonsacrificial water splitting through two-step photoexcitation by visible light using a modified oxynitride as a hydrogen evolution photocatalyst. J. Am. Chem. Soc. 132, 5858-5868 (2010).

4. Kato, S., Jung, J., Suenobu, T. \& Fukuzumi, S. Production of hydrogen peroxide as a sustainable solar fuel from water and dioxygen. Energy Environ. Sci. 6, 3756-3764 (2013).

5. Shiraishi, Y. et al. Sunlight-driven hydrogen peroxide from water and molecular oxygen by metal-free photocatalysts. Angew. Chem. Int. Ed. 53, 13454-13459 (2014).

6. Fukuzumi, S., Yamada, Y. \& Karlin, K. D. Hydrogen peroxide as a sustainable energy carrier: electrocatalytic production of hydrogen peroxide and the fuel cell. Electrochim. Acta 82, 493-511 (2012).

7. Yamada, Y., Yoneda, M. \& Fukuzumi, S. A robust one-compartment fuel cell with a polynuclear cyanide complex as a cathode for utilizing $\mathrm{H}_{2} \mathrm{O}_{2}$ as a sustainable fuel at ambient conditions. Chem. Eur. J. 19, 11733-11741 (2013).

8. Yamada, Y., Yoneda, M. \& Fukuzumi, S. High power density of onecompartment $\mathrm{H}_{2} \mathrm{O}_{2}$ fuel cells using pyrazine-bridged $\mathrm{Fe}\left[\mathrm{M}^{\mathrm{C}}(\mathrm{CN})_{4}\right]\left(\mathrm{M}^{\mathrm{C}}=\mathrm{Pt}^{2+}\right.$ and $\mathrm{Pd}^{2+}$ ) complexes as the cathode. Inorg. Chem. 53, 1272-1274 (2014).

9. Shaegh, S. A. M., Ehteshami, S. M. M., Chan, S. H., Nguyen, N.-T. \& Tan, S. N. Membraneless hydrogen peroxide micro semi-fuel cell for portable applications. RSC Adv. 4, 37284-37287 (2014).

10. Yamada, Y., Yoneda, M. \& Fukuzumi, S. High and robust performance of $\mathrm{H}_{2} \mathrm{O}_{2}$ fuel cells in the presence of scandium ion. Energy Environ. Sci. 8, 1698-1701 (2015)

11. Hisatomi, T., Kubota, J. \& Domen, K. Recent advances in semiconductors for photocatalytic and photoelectrochemical water splitting. Chem. Soc. Rev. 43, 7520-7535 (2014).

12. Kudo, A. \& Miseki, Y. Heterogeneous photocatalyst materials for water splitting. Chem. Soc. Rev. 38, 253-278 (2009).

13. Mi, Q., Coridan, R. H., Brunschwig, B. S., Gray, H. B. \& Nathan, S. L. Photoelectrochemical oxidation of anions by $\mathrm{WO}_{3}$ in aqueous and nonaqueous electrolytes. Energy Environ. Sci. 6, 2646-2653 (2013).

14. Hill, J. C. \& Choi, K.-S. Effect of Electrolytes on the Selectivity and Stability of n-type $\mathrm{WO}_{3}$. J. Phys. Chem. C 116, 7612-7620 (2012).

15. Pesci, F. M., Cowan, A. J., Alexander, B. D., Durrant, J. R. \& Klug, D. R. Charge carrier dynamics on mesoporous $\mathrm{WO}_{3}$ during water splitting. J. Phys. Chem. Lett. 2, 1900-1903 (2011).

16. Mase, K., Ohkubo, K. \& Fukuzumi, S. Efficient two-electron reduction of dioxygen to hydrogen peroxide with one-electron reductants with a small overpotential catalyzed by a cobalt chlorin complex. J. Am. Chem. Soc. 135, 2800-2808 (2013).

17. Fukuzumi, S. et al. Catalytic four-electron reduction of $\mathrm{O}_{2}$ via rate-determining proton-coupled electron transfer to a dinuclear cobalt- $\mu$-1,2-peroxo complex. J. Am. Chem. Soc. 134, 9906-9909 (2012).

18. Chen, Z., Concepcion, J. J., Song, N. \& Meyer, T. J. Chloride-assisted catalytic water oxidation. Chem. Commun. 50, 8053-8056 (2014).

19. Nakagawara, S. et al. Spectroscopic characterization and the $\mathrm{pH}$ dependence of bactericidal activity of the aqueous chlorine solution. Anal. Sci. 14, 691-698 (1998).

20. Huang, L. et al. $\mathrm{Cl}^{-}$making overall water splitting possible on $\mathrm{TiO}_{2}$-based photocatalysts. Catal. Sci. Technol. 4, 2913-2918 (2014).

21. Miseki, Y. \& Sayama, K. High-efficiency water oxidation and energy storage utilizing various reversible redox mediators under visible light over surface-modified $\mathrm{WO}_{3}$. RSC Adv. 4, 8308-8316 (2014).

22. Saito, R., Miseki, Y. \& Sayama, K. Highly efficient photoelectrochemical water splitting using a thin film photoanode of $\mathrm{BiVO}_{4} / \mathrm{SnO}_{2} / \mathrm{WO}_{3}$ multi-composite in a carbonate electrolyte. Chem. Commun. 48, 3833-3835 (2012). 
23. Kadish, K. M. et al. Electrochemistry, spectroelectrochemistry, chloride binding, and $\mathrm{O}_{2}$ catalytic reactions of free-base porphyrin-cobalt corrole dyads. Inorg. Chem. 44, 6744-6754 (2005).

24. Melis, A. Solar energy conversion efficiencies in photosynthesis: minimizing the chlorophyll antennae to maximize efficiency. Plant Sci. 177, 272-280 (2009).

25. Armarego, W. L. F. \& Chai, C. (eds) Purification of Laboratory Chemicals 7th edn (Butterworth-Heinemann, 2013)

26. Krasnoslobodtsev, A. V. \& Smirnov, S. N. Effect of water on silanization of silica by trimethoxysilanes. Langmuir 18, 3181-3184 (2002).

27. Rouquerol, F., Rouquerol, J. \& Sing, K. in Adsorption by Powder \& Porous Solid (Academic, 1999).

28. Izutsu, K. in Electrochemistry in Nonaqueous Solutions (Wiley-VCH GmbH \& Co. KGaA, 2009).

29. Matsubara, C., Kawamoto, N. \& Takamura, K. Oxo[5, 10, 15, 20-tetra(4-pyridyl) porphyrinato]titanium(IV): an ultra-high sensitivity spectrophotometric reagent for hydrogen peroxide. Analyst 117, 1781-1784 (1992).

\section{Acknowledgements}

This work was supported by an Advanced Low Carbon Technology Research and Development and SENTAN projects from Japan Science Technology Agency to S.F. and Grants-in-Aid (Nos. 24350069 and 25600025 to Y.Y.) for Scientific Research from Japan Society for the Promotion of Science (JSPS). K.M. gratefully acknowledge support from JSPS by Grant-in-Aid for JSPS fellowship for young scientists (No. 25•727).

\section{Author contributions}

S.F. conceived and designed the experiments. K.M., M.Y. and Y.Y. performed the experiments and analysed the data. S. F., K.M., M.Y. and Y.Y. co-wrote the paper.

\section{Additional information}

Supplementary Information accompanies this paper at http://www.nature.com/ naturecommunications

Competing financial interests: The authors declare no competing financial interests.

Reprints and permission information is available online at http://npg.nature.com/ reprintsandpermissions/

How to cite this article: Mase, K. et al. Seawater usable for production and consumption of hydrogen peroxide as a solar fuel. Nat. Commun. 7:11470 doi: 10.1038/ncomms11470 (2016).

(c) (i) This work is licensed under a Creative Commons Attribution 4.0 International License. The images or other third party material in this article are included in the article's Creative Commons license, unless indicated otherwise in the credit line; if the material is not included under the Creative Commons license, users will need to obtain permission from the license holder to reproduce the material. To view a copy of this license, visit http://creativecommons.org/licenses/by/4.0/ 